\title{
Two Karaim Religious Poems by Isaac ben Abraham Troki ${ }^{1}$
}

\section{Henryk Jankowski}

Adam Mickiewicz University

\begin{abstract}
This article presents two Karaim religious hymns attributed to the famous Lithuanian Karaite sage, Isaac ben Abraham Troki (1533-1594), the best known Lithuanian Karaite scholar in Europe, author of Hizzuk Emuna 'The strengthening of faith', which was translated into a number of European languages. The poems were found in two Karaite manuscripts, one undated, the other dated $1686{ }^{2}$
\end{abstract}

\section{Keywords}

Isaac $b$. Abraham Troki, Karaim poems, $16^{\text {th }}$ century

\section{Introductory notes}

Like all educated Karaites, Isaac ben Abraham Troki ${ }^{3}$ wrote his works in Hebrew, which was the literary language of the Karaites. He also knew Latin and Polish, and naturally Karaim, the spoken language of Karaite communities in Eastern Europe. Isaac ben Abraham is also believed to have composed poems in Karaim which circulated in manuscripts. According to Nemoy (2007: 156), some of Isaac ben Abraham's hymns have been included in the official Karaite prayer book. This opinion is shared by EL'JAŠEvič (1993: 37) who says that Isaac ben Abraham composed many outstanding poems, only some of which

1 I am indebted to the anonymous reviewers of this article for their critical input which I considered and responded to in my revisions.

2 My warmest thanks go to Ms. Olga Vasilieva from the National Library of Russia, St. Petersburg, for making the manuscripts available for research and publication as well as to Prof. Piotr Muchowski for help with reading Hebrew passages and other assistance.

3 Although Isaac ben Troki was very famous, we know little about his life, see e.g. EL'JAŠEvič (1993: 36-37) and Neмоy (2007: 155-156). 
were published in the prayer book. However, these authors do not tell us anything about the language of Isaac ben Abraham's poems.

For the first time a poem by Isaac ben Abraham, although in a South-West Karaim phonetic adaptation, was published by Aleksander Mardkowicz in the volume Zemerter 'Hymns' (1930:1), together with a few other poets from Lithuania, e.g. Zarah ben Natan. The poem in question is Ne była utrulajym 'What shall I meet (you) with?'. The next publication in which two other poems by Isaac ben Abraham appeared was Mikhail Firkovič's anthology Karaj jyrlary 'Karaim Songs' (1989). Isaac ben Abraham's poems, among which we find one of our hymns, were placed at the beginning of the section Es'ki jyrlar 'Old Songs' (FIrKovIČ 1989: 181-182). Firkovič's anthology was the fruit of the awakening of spiritual life among the Karaites after the long, dark period of Soviet authoritarian rule in Lithuania. Both Mardkowicz's and Firkovič's publications were addressed to the Karaite community and not to scholars. Therefore, there is no information on either the sources of the poems or the manuscripts from which they were excerpted. Some have even cast doubts on the authenticity of the poems edited by Firkovič. We can now confirm with absolute certainty the authenticity of at least the latter poem (Йанғур (йамғур) йувса йузунь йернинь йашарыр), but a comparison of language features and style leaves no doubts as to the authenticity of the former as well.

The songs in Firkovič (1989) have no titles, one begins with Йигит оян, не юклэйсын | Кюнь кысхадыр кёрямусень 'Wake up, young man, why are you sleeping | the day is short, do you see that', the other with Йанғур (йамғур) йувса йузунь йернинь йашарыр 'If the rain washes the surface of the earth, it turns green'.

The publication and edition of these texts is of particular interest to the history of West Karaim, since there are very few published old documents in this language. ${ }^{4}$ Moreover, Kowalski in his classical study confirmed that most texts possessed by the Karaites in Troki are relatively new, and the oldest manuscripts with the translations of the Bible he had seen stem from the first half of the $18^{\text {th }}$ century (KoWALSKI 1929: Xx), similarly PRITSAK (1959: 323). It is likely that older texts were acquired by Abraham Firkovich and then sold

4 One of the few is Firkovičius's edition of the proverbs with facsimile, dated 1798 (FIRKovičIUS 2000: III). 
to the Imperial Public Library of Russia (at present the National Library of Russia), where they are now stored.

\section{Description of the manuscripts}

Both manuscripts in which the hymns of Isaac ben Abraham Troki were found are kept in the National Library of Russia, St Petersburg. The microfilms are available at the Institute of Microfilmed Hebrew Manuscripts at the National Library of Israel and have their own descriptions.

It is certain that both manuscripts go back to a common proto-text, though it is unknown if this was the author's text or a later copy. This is because the differences between the two manuscripts are minimal; in fact there are only three in the lexicon, one in the suffixes and one in the phonetic features. Firstly, manuscript A lacks the word yuvunganlar, present in $\mathrm{B}$, but this must be a simple omission caused by lack of the copyist's concentration. Secondly, the copyist of A added a word after yasavulundan, evidently for the same reason, which he later erased after realising his mistake. Thirdly, the word yazïqlïlarnïn, used in B, was written as yazïqlarnïn in A, whereby the copyist transformed the 'sinner' to the 'sin', most probably also due to an unintentional omission of the suffix $+l I$.

Even the vowelling of the consonants is in both manuscripts almost identical. Some minor differences in vocalisation can be related to incidental mistakes, as shown above. There is one important differentiating phonetic feature which will be discussed later in the section on language features.

In contrast, the text in the manuscript published by Firkovič must be different, since there are more differences in suffixes and words which demonstrate that the copyist had transformed the original text purposely, e.g. A yetärsin yahšilïqqa, B yetärsen yaȟšilïqqa 'you will acquire goodness', Firkovič (182) йетярсинь йахшыльхны; A, В Yigit yigit yїlar yaman etivčü yalïndan yamanlïgïnїn, Firkovič (182) йигить йигить йылар йаманльх йесиси йалындан йаманлығынын, though both having the same meaning 'O young man, the wrongdoers will weep (being repaid) for their evil deeds'. The final part in the two versions was the most remarkable: A, B Yamannïn yürägi yarïlïr. Yarasï yazïqlarnïn / yazïqlïlarnïn yayïlïr yemišin yollarïnïn yištïrïr 'The heart of wrongdoers will break. The wound of the sinners will spread, and will collect the fruits of their road', Firkovič (182) Йуряги йарылыр йарасы 
йазыхлыларнын йайлылыр, Йемишинь йолларынын йыштырырлар 'Their / his heart will break, the wound of the sinners will spread, they will collect the fruits of their road'.

Contrary to Firkovič, who published the poems in a transcription based on the alphabet employed in the standard Karaim-Russian-Polish dictionary (KRPS), for these older texts a standard Turkological transcription is applied. This resembles the transcription as employed in Philologiae Turcicae Fundamenta with the only difference being that $\dot{g}$ is used for both the velar stop and the fricative $\gamma$. This is because the KRPS alphabet was designed for modern Karaim, while these poems were written four hundred years earlier and display the language as it was used in the $17^{\text {th }}$ century at the latest. In my opinion, we cannot project the phonological processes occurring in $20^{\text {th }}$-century Lithuanian Karaim when it was first seriously studied onto a much earlier stage of the language. For example, there are no traces of the consonant palatalisation that appeared under the Slavic influence.

\subsection{Manuscript A}

According to the description of the microfilm ${ }^{5}$ of the original manuscript, shelf number Evr I 699, it is a commentary on the precepts of faith called Peruš 'al 'iqqare ha-emuna by Isaac ben Abraham Troki on Adderet Eliyyahu, i.e. the code of law by Eliyahu Bashyachi, printed in Istanbul (Kustandina) in 1530/1531 (see Poznanski 1918: 35). Although the microfilm description dates the manuscript to the $18^{\text {th }}$ century, it is clear that it is older, since the colophon shows the date 1686 .

The manuscript contains 18 folios. The foliation of the entire manuscript written in pencil with Arabic numerals is later, but the first part of the manuscript, folios 1-10, also has foliation in ink with Hebrew letters from $\aleph$ to '.

The manuscript is composed of two parts. The title of the first part on 1a reads Ve-ze peruš hu 'al aśara ha-'iqqarim mi-sefer Mișvot še-hu Adderet Eliyya$h u$ 'This is a commentary to ten articles of faith from the Book of Precepts i.e. Adderet Eliyyahu'. Then, it continues: 'It is my lord, instructor and master, esteemed great teacher Isaac from Trok, may the memory of this righteous, holy man be blessed, son of our respected teacher Abraham, may his memory be

\footnotetext{
5 At the Institute of Microfilmed Hebrew Manuscripts, National Library of Israel.
} 
blessed'. The text ends on 10a where there is the colophon, showing the date 445, i.e. 1686 CE. The name of the copyist is Mordecai ben Isaac. ${ }^{6}$

The next part of the manuscript which contains the Karaim poems begins on 11a. It begins with the words:

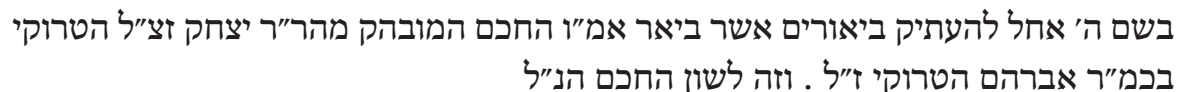

'In the name of God, I am starting to copy the comments by my lord, teacher and master, distinguished sage Rabbi Isaac, the righteous scholar of blessed memory from Trok. This is what the aforementioned sage said'.

Therefore, it is evident that this part of the manuscript also contains a text by Isaac ben Abraham Troki. The Karaim poems are written on two pages, $15 \mathrm{~b}$ and 16a. On 15b, the Karaim text begins on line 14 and runs to the end of the page (line 23), then continues on the next page, being signalled by the catchword yapraqlay 'like a leaf' on page $15 \mathrm{~b}$; line 16 and the end of line 21 on this page being in Hebrew. The next page, folio 16a, is all Karaim except lines 4 and 9 (written within the parentheses; an evident local Polish impact) as well as the last two lines (19-20). The first, longer poem takes up the whole of page $15 \mathrm{~b}$ and lines 1-9 of 16a, while the second, shorter one is found on 16a: 10-18.

In lines 8-12 on 15b the copyist writes that the poem, i.e. both verses taken for one, was composed by Isaac ben Abraham Troki in the Ishmaeli language (i.e. the vernacular).

Just after the Karaim text (16b-18b), there is a Hebrew translation of Isaac ben Abraham's first poem by Yehuda ben Zerubbabel, called Bet Yehuda. This is in fact a paraphrase with many amplifications. Yehuda ben Zerubbabel divided his translation into four parts according to four Hebrew phrases present in the original poem. ${ }^{7}$

6 We know nothing about him. He is not mentioned on Poznanski's list of Karaite copyists (PozNANSKI 1916), nor in EL'JAŠEvič (1993).

7 Yehuda ben Zerubbabel's translation must also have been popular with the Karaites, for a copy of it is found in the first part of manuscript Abkowicz 3 (personal communication by Piotr Muchowski). It is to be noted that only the second part of this manuscript was 
As for the writing, Hebrew and Karaim fragments were written in different styles. The Karaim text was written with larger, thicker letters, slightly slanted from right to left. The letters are fully vowelled, while the Hebrew text in this manuscript is not. Most likely, the second part was also copied by Mordecai ben Isaac.

\subsection{Manuscript B}

Manuscript B, shelf number Evr IIa $161^{9}$, is undated, and probably copied in the $18^{\text {th }}$ century. There is no colophon in it, and therefore the name of the copyist is unknown. The catalogue description written in Russian, most probably Abraham Firkovich's work, presents the contents of the manuscript. It begins with the following words, Сборникъ разньхъ статей и стиховъ изъ соч.

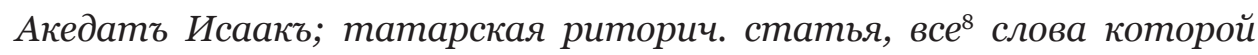
начин. буквой і Исаака Троки [...] 'A collection of various articles and poems from the work 'Aqedat Ishaq; Tatar rhetoric article [!] of Isaac Troki whose words all begin with the letter $y$ '. The note says that the manuscript has eighteen folios written in the Rashi style. Since this short manuscript contains more works rather unrelated to our topic, in the following I will concentrate solely on Isaac ben Abraham Troki's poems. The manuscript has foliation 1-18, and from folio 7 the foliation is doubled, running at the bottom and the top of each relevant folio. It should be added that the manuscript also contains a Hebrew prayer (7b-10a) the words of which begin with an identical letter $(m)$, with a closing Hebrew formula written in Roman script of Polish style (10a).

The Karaim poems are written on two pages, $5 \mathrm{a}$ and $5 \mathrm{~b}$. The Karaim text starts on line 4 and runs to the end of the page, line 21, then continues on folio $5 \mathrm{~b}$, lines $1-4$. The first, longer poem is written on lines $5 \mathrm{a}: 4-17$, whereas the second, shorter one runs from $5 \mathrm{a}$ : 19 to $5 \mathrm{~b}: 4$.

In contrast to the Hebrew text of the manuscript, the Karaim poems, as in the previous manuscript, are vowelled, but the writing is the same, except for the incipits which are slightly larger in size. The Karaim text is separated from the Hebrew in the beginning and the end by an ornamental design, more

edited (Muchowsкi 2013); in it, incidentally, there are two short Hebrew poems by Isaac ben Abraham Troki (p. 301).

8 A word corrected in the description. 
simple at the end and more elaborate at the beginning, similar to some parts of these manuscripts.

\section{Language features}

The first poem is composed as an exemplum with advices to the reader or listener, but also with some admonitions for their behaviour. It contains some natural and some moral truths. The utterances are presented in the form of both declarative and imperative clauses. All imperative clauses have VO word order, e.g. yengin yaman yecerinni 'defeat your evil nature', with actants expressed by the verb, which can be considered non-Turkic. However, linguistic literature considers such a sentence to be a special kind, calling it regressive (predicate-basis) in contrast to the usual Turkic SOV, which is progressive (basis-predicate) and relates their order to the informational structure of the utterance or other reasons. Such sentences are known in all Turkic languages and they were, e.g., analysed in Kazakh by Pankrac and Žarmakin (1971).

Declarative clauses include the following: (1) with intransitive verbs, 14 of which have SV word order, while 9 have VS, including two - $p$ converbs; (2) there is only one transitive verb with (S)OV word order. Present participles have an inverted word order, e.g. yïlïs etivčü yalïn yalčinïn 'he who destroyed the job of the servant'. It is interesting that unlike the common Turkic verb yet- '1. to reach; to attain; to arrive. 2. to be enough', which is intransitive and requires the complement in the dative, in this verse it governs the complement in the accusative, i.e. yalïn yetsä 'if he gets his wages'. This is not a scribal mistake, since a similar valency is attested in Firkovič's version in jet'arsin' jaxšylхny (йетярсинь йахшыльххны), as opposed to A, B yetärsen yahšilizqqa 'you will acquire goodness', cf. above. Therefore, this means that $16^{\text {th }}$-century Troki Karaim allowed both types of valency, probably under Polish influence, cf. Polish zdobyć coś.

With regard to nominal phrases, adjectival attributes always precede the verb, e.g. yaḥši yol 'good path' as in normal Turkic syntax, which is not always the case in Karaim translations from Hebrew (JANkowski 1997: 19). However, in genitive constructions, an inverted HEAD GENITIVE word order is represented by fourteen phrases and normal Turkic GENITIVE HEAD word order occurs only once in yamannïn yürägi 'the heart of wrongdoers'.

The second poem is composed in the form of a supplication, more exactly a priestly encouragement that the believers deliver petitions to God. The verse 
begins with an appeal to the congregation, which is the nominal phrase Yiyïnï Yisraelnin! 'Congregation of Israel!'. The inspiration for the believers has the form of $2^{\text {nd }}$ person singular imperative in -QIn, yalbargïn (yaratuvčumuzg்a) 'Beg (our Creator)', while the action expected from God is expressed by the $3^{\text {rd }}$ person singular optative-QAy. There are thirteen verbs in the optative in this short hymn, yapqay 'that He absolve, lit. close', yengillätkäy 'that He make

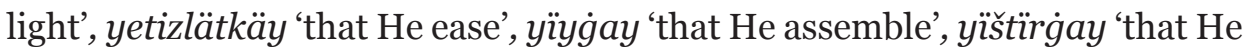
gather', yulugay 'that He save', yomdargay 'that He gather', yasagay 'that He restore, lit. make', yuvutqay 'that He bring close', yaratqay 'that He give, lit. create', yetkirgäy 'that He bring', yangïrtqay 'that He renew', only one in the plural, yalčig ${ }^{2}$ ylar 'that (they) be happy', being referred to the righteous. All sentences, including those with the -QIn imperatives, begin with the verb, i.e. the word order is VO, with $\mathrm{S}$ as the actant being expressed by the verb. Although such sentences are marked by a pragmatic function and an inverted word order is motivated, there is very likely an indirect influence from Hebrew. It should be noted that supplications in Christian and Muslim Turkic prayer books also frequently begin with a verb.

Other features are similar to those in the first verse, i.e. there is a non-Turkic HEAD GENITIVE, but a normal ATTRIBUTE HEAD word order. There is a relatively high number of past participles, yesirlängän 'captivated (translated 'captive')', yadagian 'tired (translated 'feeble')', yolqungan 'oppressed', yuzaqlangan 'surrounded', yïyïlgan 'fallen down, destroyed (translated 'ruins')', yag̈ilgan 'anointed', all passive, if formed from transitive verbs. This should not be attributed to Turkic, since participles in such functions are also frequent in Hebrew religious texts.

In conclusion, we can say that at least in its religious, literary style, the syntax of $16^{\text {th }}$ - century Troki Karaim demonstrates some non-Turkic syntactic features: one in nominal phrases, and more in verbal clauses. Although there are many articles and observations on specific Karaim linguistic features, due to the lack of historical material, most of them were formulated on the basis of modern material and $18^{\text {th }}$ - and $19^{\text {th }}$-century translations, not original works. Therefore, a general conclusion was that the innovations were induced by language contact. However, as Csató (1998: 83) assumed, some specific features of Karaim "may even be very old developments".

A remarkable phonetic feature that distinguishes the two manuscripts is the notation of the consonant $y$ in the $2^{\text {nd }}$ person possessive suffix in manuscript $\mathrm{A}$, 
as opposed to manuscript B in which it is $n$. In other words, the older manuscript of 1686 evidences the change of common Turkic $y$ to $y$ in this suffix as it is in the present-day Troki Karaim, in contrast to the change $y \rightarrow n$ in Łuck-Halicz Karaim and the retention of $y$ in Crimean Karaim. Therefore, we have evidence that this change was already completed at the end of the $17^{\text {th }}$ century. It is unknown why the copyist of B wrote $n$ in all cases where A has $y$, e.g. yaratuvčun 'your Creator' instead of yaratuvčuy. We may suppose that he was a native speaker of Łuck-Halicz Karaim or/and regarded the Troki Karaim change $\eta \rightarrow y$ as abnormal, colloquial and thought that $n$-form was the better one. Initially I hypothesised a change $\eta \rightarrow n \rightarrow y$ and the possibility of an older manuscript used by B in which the presumable change would stop at the stage $\eta \rightarrow n$, but unfortunately, the change $n \rightarrow y$ is not typical and it is not attested in other Turkic languages. In short, Proto-Turkic ${ }^{*} \eta$ in the suffix $+(X) \eta^{9}$ shifted in West Karaim either to $+(X) n$ or $+(X) y$, probably the letter through [j]]; therefore the presumable change would be $\eta^{*} \rightarrow \tilde{y} \rightarrow y$. It should be noted that this change in Troki Karaim is curious since in other cases we have $\eta \rightarrow n$. It is worth noting that in Łuck-Halicz Karaim the change to $n$ occurred in all suffixes (ZAJĄCZKOWsKI 1931: 15, 16, 19, 25) and many stems; ${ }^{10}$ the retention of $y$ in Crimean Karaim is also quite consistent, with only a few exceptions, mostly influenced by Turkish.

On the whole, it can be argued that in the $16^{\text {th }}-17^{\text {th }}$ centuries Karaim preserved its Turkic character fairly well, apart from syntax. The evidence of syntactic constructions is of special interest. We have to keep in mind that the poems are original Karaim works, not translations, ${ }^{11}$ and neither Hebrew nor Polish could directly affect the syntactic structures of their language, though the indirect influence of Hebrew liturgy is indisputable. The constraint imposed by alliteration is also ineffective, for it concerns all words on an even basis. However, as we will see, many syntactic constructions reveal non-Turkic word order, typical of Karaim as we know it from present-day West Karaim.

There is some new lexical material in the poems edited. The words unattested in the dictionaries are yetizlet- 'to ease something up' $\leftarrow$ yetiz-; yištïr- 'to

9 Also in some other suffixes which, however, do not occur in the present texts.

${ }^{10}$ However, as KowaLSKI (1929: LIV) demonstrated, in some stems $y \rightarrow y$, e.g. iaiak 'cheek'. Despite this Musaev (1964: 40) claims that this change in Halicz Karaim has taken place in all cases.

${ }^{11}$ In contrast to three hymns edited by Munkácsi (1909) which are translations from Hebrew. 
gather, to assemble, to collect' (so far only the passive form being attested); yolugiuš 'something encountered' $\leftarrow$ yoluq- 'to encounter'; yuzaqlan- 'to be locked; fig. to be surrounded' $\leftarrow$ yuzaq 'lock'; yüvrük 'runner; who runs; fig. diligent' $\leftarrow$ yüvür-. The verb yuvur- appears in the front form yüvür-. Some words occur in the meanings different than the usual one, e.g. yasavul in one of the poems denotes 'making; creating'.

Most words are Turkic. There is only one word derived from an Arabic stem yesirlängän $\leftarrow$ yesir 'captive' $\leftarrow$ asīr, one Persian yavan 'desert; wilderness' $\leftarrow$ Per. yābān 'id', and one Hebrew, yecer 'nature; character', if we disregard proper names which are naturally all Hebrew. So far the word yecer has only been shown from Halicz dialect.

\section{The poems and their literary value}

The two poems by Isaac ben Abraham published here are considered by the copyists a single poem, probably because of the alliteration which is a feature common to both and the fact that one comes after another without any major dividing symbols or characters. In addition, in manuscript B both are separated from the rest by an ornamental design. Although both poems are composed by the same author, they differ in literary genre. It is worth examining how the famous Karaite sage was successful with these Karaim poems. If we try to answer this question, we have to stress that the poems function in the contexts of the major Hebrew composition, even if they are not translations. However, despite the textual Hebrew dependence which is not shown in Firkovič's edition, in our opinion they may be treated as independent literary works.

As said above, the first verse is a kind of exemplum with elements of encouragement and admonition, while the second is a supplication. Both are religious; the former instructs the reader what he will get if he is good and if he is evil, encouraging him to do good deeds, e.g. yalvargïn yïlamaq-bïla 'entreat and weep', yuvgiun yüzün yürägiynin 'cleanse your heart', yengin yaman yeceriyni 'defeat your evil nature'.

The poems were principally aimed to be hendecasyllabic, though some verses have less syllables and some have more. Although there are some recurring patterns, on the whole the rhythmic structure of the lines is irregular.

The most characteristic feature of both poems is that all words begin with the letter yod. In the first poem there are more than 100 words with an initial 
$y$ (according to Yehuda ben Zerubbabel 112), while in the second the number is 50, including proper names. Therefore, we have an example of full initial alliteration. It is to be noted that this rule of verse composition is quite characteristic of genuine Turkic poetry, ${ }^{12}$ though full alliteration is rarely observed. Turkic alliteration is both interversal, if a few verses begin with the same sound, or intraversal, if all words in a verse begin with the same sound. Turkic poems are often both interversal and intraversal, albeit due to formal constraints pure examples of long, full alliteration seldom occur. Despite the common use of alliteration in Turkic folk poetry, this technique cannot be exclusively bound to Turkic influence, since alliteration is also encountered in Hebrew texts (see above).

In addition to alliteration, some feet show assonance, e.g. yemin yesä yesi [...] 'if one eats the food of [...]' or yigit yigit yüvürgün 'O young man, run', which in some cases rises as a product of vowel harmony, e.g. yuvgin yüzün 'wash the face [of ...]'. In a few other cases, intraversal alliteration shifts to consonance, e.g. yïygay yïyïnïn 'that He assemble the crowds [of ...]'. All this makes parts of the poems beautiful and smooth.

Needless to say, composing a poem of more than a hundred words so that all could begin with the same sound, even if individual words are repeated, is very difficult and requires a great mastery from the poet. It must be acknowledged that the task posed to Isaac ben Abraham was too hard to be successfully carried out, even if some portions of the verses are correct. As a result, there are some portions of the verses which are not only less perfect formally, but simply clumsy, e.g. Yïgïlïr yaman yïg̈̈lmaq yïlïs etivčü yalïn yalčinïn 'Those who destroyed the job of the servant will fall down', with no clearly indicated subject.

In short, we may say that the formal constraints have made the author unable to compose ideal poems. Moreover, composition of a long alliterated poem inevitably leads to repetitions. For instance, the words yigit 'young man' and yol 'road, path' are repeated in the first poem seven times each.

In spite of this, the literary works by Isaac ben Abraham edited here, which are the oldest pieces of Turkic Karaite literature known to date, ${ }^{13}$ are very

12 Cf. e.g. Zieme (1991), Doerfer (1996: 69-194).

13 If we disregard two short pieces in Karaite Turkish in the Venice prayer book of 1528/1529, for the the latest discussion see SHAPIRA (2003: 691-692), AQTAY (2009: 19) and JANKOWSKI (2012: 53-55). 
valuable as unique evidence of $16^{\text {th }}$-century North-West Karaim. Moreover, although religious in character and in the Hebrew context, the poems edited and discussed here are original works, not translations. Even if formally far from perfect, the poems demonstrate great mastery on the part their author.

We can only hope that the analysis of other early short Karaim texts discovered in the archives will make available works which did not compel their authors to such a juggling, or at least we will be able to find manuscripts with the works already edited by Mardkowicz and Firkovič.

\section{Poem I}

\section{[15b]}

[14] Yamġur yuvsa yüzün yernin yašarïr.

Yemin yesä yesi yolnun yüvürür. ${ }^{14}$

[15] Yüvrük ${ }^{15}$ yalčì yalïn yetsä yuvanïr.

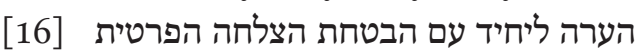

[17] Yigit yigit yüvürgün yoluna yaratuvčuynun ${ }^{16}$

Yalvargïn yillamaq-bïla

[18] Yuvġun yüzün yürägiynin. ${ }^{17}$

Yengin yaman yeceriyni. ${ }^{18}$

Yarlïgašïì $^{19}[19]$ yalïnlay ${ }^{20}$ yarïr.

Yigitligiy ${ }^{21}$ yaštagiilay yangïrïr. Yabulur yazïgïy. ${ }^{22}$

[20] Yašïrïlïr yamanlïgïy. ${ }^{23}$

${ }^{14}$ KRPS only T, H, K yuvur- (253), but K yüvürt- 'to carry, to fetch' (261); front reading is clear from the letter $k a f$ in the derivative yüvrük.

15 Absent from KowaLski (1929) and KRPS.

16 B 5a:6 yaratuvčunnun.

17 B 5 a:7 yüreginnin.

18 B 5a:7 yecerinni; from Heb. יִֶֶ. which means '1. instinct; impulse. 2. inclination, nature. 3. desire', the pronunciation yečer being also possible; KRPS evidences this word only from the Halicz dialect as yecer 'character, look' (278), without any etymological indication; see also MARDкоwicz (1935: 34) jecer 'charakter, konsystencja | Bestand, Charakter'. In Firkovič's edition йецерийни.

19 B 5a:7 yarlïgašin.

${ }^{20}$ On the adverbal suffix -lAy see Musaev (1964: 189).

${ }^{21}$ B 5a:7 yigitligin.

${ }^{22}$ B 5a:8 yazïgïn.

${ }^{23}$ B 5a:8 yamanlïgïn. 
Yolug̉ursïn ${ }^{24}$ yaḥši yolugiušlarg̉a. ${ }^{25}$

Yetärsin ${ }^{26}$ [21] yah.šilïqqa. ${ }^{27}$ שכר הצדיקים

[22] Yigit yigit yüvrüklär yaḥši yolg̀a,

Yarlïgašïna yoġargïnïn yetärlär.

[23] [Yuvunġanlar] ${ }^{28}$ yazïqlardan yolduzlay yarïrlar.

Yuvuz yüräklilär [16a][1] yapraqlay yašarïrlar.

Yaštan yigittän yoluna yaratuvčunun yüvürürlär.

[2] Yetip yillarga yasavulundan ${ }^{29}\{\ldots\}$ yolunun yogarg̈ïnïn yubanïrlar.

[3] Yomulup yerdän yoġarg̈i yarlïgašlarġa yetärlär. ${ }^{30}$

ע4] [4] הרשעים

[5] Yigit yigit yïlar yaman etivčü yalïndan ${ }^{31}$ yamanlïginï̈n.

Yadar yetkirüvčü [6] yolun ${ }^{32}$ yillarnïn.

Yigiilïr yaman yïgïlmaq yilïs etivčü [7] yalïn yalčinïn.

Yabulur yerdä33 yïyïnï yamanlarnïn.

Yamannïn yürägi yarilïr,

[8] Yarasï yazïqlïlarnïn ${ }^{34}$ yayilïr yemišin yollarïnïn yïštïrïr. ${ }^{35}$

[18]

Translation

[15b]

[1] If the rain washes the surface of the earth, it turns green.

If the traveller eats its food, he will run.

[15] The running servant ${ }^{37}$ will rejoice if he gets his wages.

${ }^{24}$ yolugiursen, written with a șere (צֶירֶ).

${ }_{25}$ The word is absent from KRPS; FIRкоvIč 182: йоллуғушларға.

${ }^{26}$ B 5a:9 yetärsen, the letter $s$ vowelled by a segol.

27 Firkovič 182: йахшылыхны.

${ }^{28}$ The word is absent from A, but present in B and in Firкоvič 182 as йувунғанлар.

${ }^{29}$ There is an erased word after this.

${ }^{30}$ This verse is absent from Firkovič's edition.

${ }^{31}$ Firкovič 182 йаманльх йесиси.

${ }^{32}$ Firkovič 182 йалын.

33 The word is absent from B; Firкоvгс̌ 182 йувуз йердя.

${ }^{34}$ yazïqlarïnïn; corrected on the basis of B 5a:17.

35 Firkovič 182: йыитырырлар.

${ }^{36}$ In A 16a:4 this Hebrew phrase is in parentheses which shows the influence of western punctuation.

${ }_{37}$ The word yüvrük, although translated literally, should be understood as 'diligent'. 
[16] Notes to one, it will be beneficial for him

[17] O young man, run God's path, Entreat and weep.

[18] Cleanse your heart, ${ }^{38}$

Defeat your evil nature.

Your mercy [19] will glow in the light.

You will return to your youthfulness,

You will be absolved from $\sin ,{ }^{39}$

[20] Your evil will be concealed.

You will encounter good things.

You will acquire [21] goodness. Reward for the righteous

[22] O young man, the fast runners ${ }^{40}$ will reach the good path

And attain the blessing of the Sublime.

[23] Those who are absolved from $\sin ^{41}$ will sparkle like the stars.

The upright [16a][1] will blossom like leaves.

The youngsters and the kids will go the Creator's path.

[2] They will enjoy the path of the Exalted when they grow old, ${ }^{42}$

[3] they will gather on earth and attain God's mercy.

[4] Punishment for the evil

[5] O young man, the wrongdoers will weep being repaid for their evil deeds. Those who caused this for so many years will get tired. [6-7] Those who destroyed the job of the servant will be destroyed. 43

The crowd of wrongdoers will be buried under earth.

The heart of wrongdoers will break.

[8] The wound of the sinners will spread,

And they will collect the fruits of their road.

[9] Notes to all and success to everybody.

${ }^{8}$ Lit. 'the surface of your heart'.

39 Lit. 'your sin will be closed'.

${ }^{40}$ I.e. those who are diligent.

${ }^{41}$ Lit. 'those who washed'.

${ }^{42}$ It is somewhat unclear; the word yasavul 'guard; officer' seems to be used here in the meaning 'making; creating', but it is not attested in this sense in Turkic languages. The word yïl in the plural here and elsewhere denotes 'age; life; long period of life'.

43 A clumsy sentence. 


\section{Poem II}

[10] Yïÿ̈ï Yisraelnin!

Yalbarg̈in yaratuvčumuzġa, yapqay yazïqlarïmïznï.

[11] Yengillätkäy yüklärimizni, yetizlätkäy ${ }^{44}$ yulunmaq yïllarïmïznï.

[12] Yìggay yïyïnïn yesirlängänlärnin.

Yištïrgay ${ }^{45}$ yadaġanlarnï yavanda.

Yulug̉ay [13] yolqunġanlarnï ${ }^{46} \mathrm{Yu}^{6}$ ušta, Ya'lamda ${ }^{47}$.

Yomdargay yuzaqlanġanlarnï ${ }^{48}$ [14] Yišma'eldä.

Yasaġay yïgïlġanlarïn Yurušalayimnin.

Yuvutqay [15] yagiilganlarnï.

Yagïnïr yav-bïla ${ }^{49}$ yoluna yumušunun.

Yaratqay yïyïnlarïna [16] Yuhudanïn yangii yüräk.

Yetkirgäy yüräklärimizni yahšsi yolġa.

[17] Yangïrtqay yilllarïmïznï yarlïgašlï yilllar kibik.

Yalčïgaylar [18] yuvuz yüräkliläri Yichaqnïn.

Translation

[10] Congregation of Israelis!

Beg our Creator

That He absolve us from sin,

[11] That He make our burden light,

That He ease the redeeming of our lives, ${ }^{50}$

44 The letter $t$ in the suffix -lät- is inserted above the line, while in B 5a:19 it is written correctly; KRPS (276) quotes only the verb йэтизле- from the Crimean dialect, glossing it as 'хитрить, замышлять; коварно, хитро поступать | chytrzyć, zamyślać chytrze, podstępnie postępować' i.e. 'to behave or act wilily, slily, in a cunning manner'; however, this meaning certainly does not apply to this poem and must be derived from the meaning of the basic adjective yetiz '1. diligent, hard-working; active. 2. prudent, cautious'.

45 KRPS (268) glosses only the passive form of this verb.

46 This is probably the participle of the verb yolqun-, absent from KowALSKI (1929), MARDKowicz (1935) and KRPS, $\leftarrow$ yulqun- 'to be plucked; to shave one's hair', for the change $u \rightarrow o$ see yulduz $\rightarrow$ yolduz.

47 See Gen 36:18 Jeush, Jalam.

${ }^{48}$ KRPS does not provide this verb, it only glosses the noun from which it is formed as йузак from Halicz-Łuck, изах from Troki, and узакъ from the Crimean dialect 'lock' $(255,194,574)$.

49 yavu-bïla; corrected on the basis of B 5b:2.

${ }^{50}$ Lit. 'that redeeming ease up our years'. 
[12] That He assemble the crowds of captives, That He gather the feeble in the wilderness, That He save [13] those oppressed by Yeush and Yalam, That He gather those surrounded by the [14] Ishmaelites, That He restore the ruins of Jerusalem, That He bring close [15] the anointed.

They will be anointed with oil on the path of their labour.

[16] That He give ${ }^{51}$ a new heart to the people of Yehuda.

That He direct our hearts towards a good path,

[17] That He renew our years to be as in the past blessed years,

[18] That Isaac's upright people be happy.

\section{Glossary}

-bïla - 'with'; yav-bïla 'with oil'.

kibik - 'as; like'.

yabul- - 'to close; to be covered'.

yada- - ' 1 . to be tired, to be exhausted. 2 . to grow lean; to weaken, to become feeble'.

yagiil- - 'to be oiled; to be anointed'.

yagïn- - 'to smear oneself, to spread sth on oneself'.

yahıši - 'good'.

yahšilìq ( gìi) - 'good, goodness'.

yal - '1. job of a hired workman, daily labourer. 2. rent, hire'.

yalbar- - 'to beg, to entreat, to implore'.

yalči - 'servant, hired hand, day labourer'.

yalči- - 'to be happy, to enjoy'.

yalïn - 'flame'.

yalvar- see yalbar-.

yaman - 'wrong, bad; evil'; etivčü 'wrongdoer'.

yamanlïq ( $\sim$ gï) - 'evil, wrongness; badness'.

yamgur - 'rain'.

yangï - 'new'.

yangïr- - 'to be restored, to be renewed'.

yangïrt- - 'to restore; to renew'.

${ }^{51}$ Lit. 'make; create'. 
yap- - 'to close; to cover'.

yapraq $(\sim \dot{g} i)-$ 'leaf'.

yara - 'wound'.

yarat- - 'to create'.

yaratuvču - 'Creator'.

yarï- - 'to shine, to glow; to sparkle'.

yaril- - 'to be split, to crack; to break'.

yarlïgaš - 'mercy, grace; salvation'.

yarlïgašli - 'blessed'.

yasa- - 'to make, to construct; to amend, to restore'.

yasavul - 'guard; officer; here making; creating'.

yašar- - '1. to become young. 2. to become green'.

yaširïl- - 'to be hidden, to be concealed'.

yaš - 'age'.

yaštagï - 'of the age'.

yav - 'oil'.

yavan - 'desert; wilderness' $\leftarrow$ Per. yābān 'id'.

yayil- - 'to be spread; to spread'.

yazïq ( $\sim \ddot{g} i) ~-~ ' s i n '$.

yazïlï - 'sinner; who sinned'.

ye- - 'to eat'.

ye - 'owner'; this word normally occurs with the 3 SL possessive suffix as yesi.

yecer - 'character, temper; nature' $\leftarrow$ Heb. יצֶ.. '1. instinct; impulse. 2. inclination, nature. 3. desire'.

yem - 'food'.

yemiš - 'fruit'.

yengillät- - 'to make lighter; to make easier'.

yen- - 'to overcome; to defeat'.

yer - '1. earth. 2. place'.

yesirlän- - 'to be captivated; to be taken captive', $\leftarrow$ Ar. asīr 'slave; prisoner of war, captive'.

yet- - '1. to reach; to attain; to arrive. 2 . to be enough'.

yetizlät- - 'to ease sth, to facilitate'.

yetkir- - 'to reach, to attain; to deliver'.

yïgil- - 'to fall down, to collapse, to fall into ruin'.

yïgilmaq - 'fall, collapse'. 
yigit - 'young man'.

yigitlik ( gi) 'the state of being a young man; youthfulness'.

yïla- - 'to weep, to cry, to lament'.

yillamaq ( gï) - 'weep, cry, lament'.

yilïs: etivčü 'who destroys'.

yil - 'year'.

yištïr- - 'to gather, to assemble'.

yïy- - 'to gather, to assemble'.

yïyïn - 'crowd, assembly, congregation; mass'.

yoġargï - 'high; elevated'.

yolduz - 'star'.

yol - 'road, way, path'.

yolqun- - 'to be plucked'.

yoluq- ( $\dot{\text { gu }}$-, $\sim \dot{\text { ga }}-)$ - 'to encounter'.

yolugiuš - 'something encountered'.

yomdar- - 'to gather; to organise'.

yomul- - 'to be gathered'.

yuban- - 'to be happy, to enjoy'.

yulu- - 'to save, to rescue; to redeem'.

yulunmaq ( $\sim$ gii) 'liberation, rescue; redeeming'.

yumuš - 'work, job, labour'.

yuv- - 'to wash'.

yuvan- see yuban-.

yuvun- - 'to be washed; to be cleaned'.

yuvut- - 'to bring near'.

yuvuz: yüräkli 'honest; upright'.

yuzaqlan- - 'to be locked; fig to be surrounded'.

yük - 'burden; load'.

yüräk ( gi) - 'heart'.

yüräkli see yuvuz.

yüvrük ( gü) - 'fast runner; fast running; fig diligent'.

yüvür- - 'to run'.

yüz - 'face; surface'. 


\section{Proper names}

Ya'lam

Yicḥaq

Yisrael

Yišma'el

Yu'uš

Yuhuda

Yurušalayim

\section{References}

AqTAY, Gülayhan. 2009. Eliyahu ben Yosef Qulcı's anthology of Crimean Karaim and Turkish literature. Vol. I Introduction, text and indexes. Vol. II Facsimile. İstanbul: Yıldız Dil ve Edebiyat Dizisi 8.

Csató, Éva Ágnes. 1998. Should Karaim Be ‘Purer’ Than Other European Languages, Studia Turcologica Cracoviensia 5 (1998), 81-89.

DOERFER, Gerhard. 1996. Formen der älteren türkischen Lyrik. Szeged [=Studia uralo-altaica 37].

EL'JAŠEvIČ 1993 = Ельяшевич, Б. С. 1993. Караимы. Книга 2. Караимский библиографический словарь (от конца VIII в. до 1960 г.). Москва: Институт Этнологии им. Н. Н. Миклухо-Маклая.

FIRкоVIČ 1989 = Фиркович, М. И. (еd.). 1989. Карай йырлары. Вильнюс: Lietuvos Kultūros Fondas, Karaimų Kultūros Bendrija.

Finkovičıus, Mykolas. 2000. Šelomonun Mašallary. Süleyman'in Meselleri. Patarliu Knyga (Proverbia). Ankara: Türk Dil Kurumu Yayıları.

JANkowski, Henryk. 1997. A Bible Translation into the Northern Crimean Dialect of Karaim, Studia Orientalia, 28, 1-84.

JANkowski, Henryk. 2012. Literatura krymskokaraimska, Przegląd Orientalistyczny $1-2,50-68$.

Kowalski, Tadeusz. 1929. Karaimische Texte im Dialekt von Troki. Kraków: Polska Akademja Umiejętności.

KRPS = БАСКАКОВ, Н. А., А. ЗАЙОНЧКОВСКИЙ, С. М. ШАПШАЛ (eds). 1974. Караимско-русско-польский словаръ. Москва: Русский Язык.

MardKowicz, Aleksander. 1930. Zemerter (Karaj sezinde). Jarykka cyhardy Aleksander Mardkowicz. Pieśni religijne Karaimów (w języku karaimskim). Wydał Aleksander Mardkowicz. Łuck. 
MardKowicz, Aleksander. 1935. Karaj sez-bitigi. Stownik karaimski. Karaimisches Wörterbuch. Łuck.

Muchowsкi, Piotr. 2013. Folk Literature of the Polish-Lithuanian Karaites. Abkowicz 3 manuscript, part 2. Paris: Editions Suger Press. Revue Européenne des Etudes Hébraïques.

Munkácsi, Bernhard. 1909. Karäisch-tatarische Hymnen aus Polen, Keleti Szemle 10, $185-210$.

MusAEV = Мусаев, К. М. 1964. Грамматика караимского языка. Фонетика и морфология. Москва: Наука.

Nemoy, Leon. 2007. Troki, Isaac Ben Abraham: Michael Berenbaum, Fred Skolnik (eds). Encyclopaedia Judaica. $2^{\text {nd }}$ edition. Vol. 20. Detroit: Macmillan, 155-156.

Pankrac, G. Ja., O. K. Žarmakin. 1971. Funktionen der Wortfolge im Aufforderungssatz (am Beispiel der gegenwärtigen kasachischen Sprache, Ural-Altaische Jahrbücher 43, 116-121.

Poznanski, Samuel. 1916. Karäische Kopisten und Besitzer von Handschriften, Zeitschrift für Hebräische Bibliographie 19, 79-122.

Poznanski, Samuel. 1918. Karäische Drucke und Druckereien, Zeitschrift für Hebräische Bibliographie 21, 32-48.

Pritsak, Omeljan. 1959. Das Karaimische: Jean Deny, Kaare Grønbech, Helmut Scheel and Zeki Veledi Togan (eds.). Philologiae Turcicae Fundamenta, Vol. 1. Wiesbaden: Franz Steiner, 318-340.

SHAPIRA, Dan. 2003. The Turkic Languages and Literatures of the East European Karaites: Meira Polliack (ed.). Karaite Judaism. A Guide to its History and Literary Sources. Leiden, Boston: Brill, 657-707.

ZAJĄCZKowski, Ananjasz. 1931. Krótki wykład gramatyki języka zachodniokaraimskiego (narzecze tucko-halickie). Łuck: Aleksander Mardkowicz.

Zieme, Peter. 1991. Die Stabreimtexte der Uiguren von Turfan und Dunhuang. Studien zur alttürkischen Dichtung. Budapest: Akadémiai Kiadó.

Henryk Jankowski, professor at the Department of Asian Studies, Adam Mickiewicz University in Poznan, is the founder of the BA and MA study programs in Turkic languages in Poznan. His recent research concentrates on Karaim, Turkish, Kazakh and other Turkic languages. 


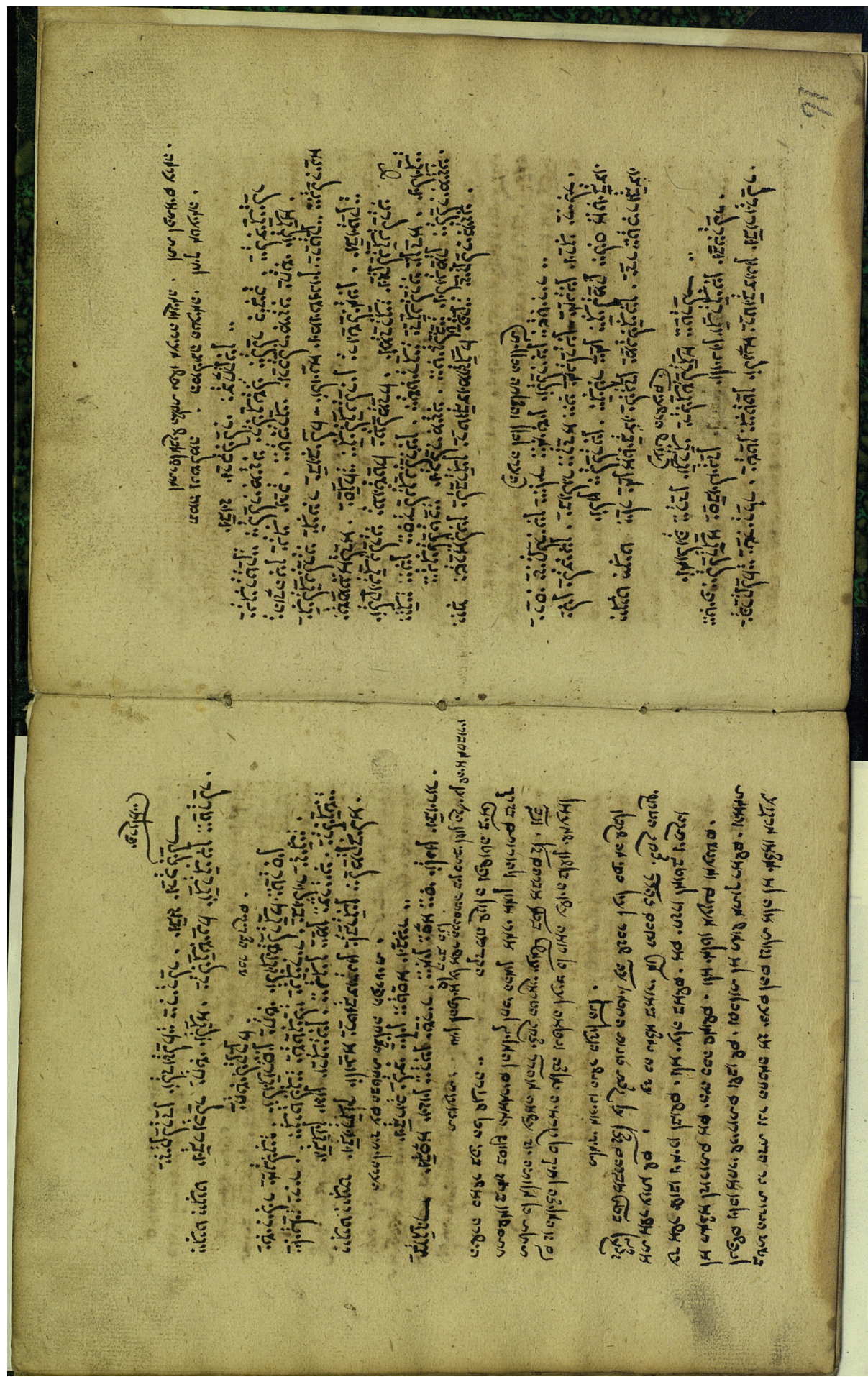

Fig. 1 Manuscript A (Evr I 699 15b-16a, National Library of Russia, St Petersburg). 


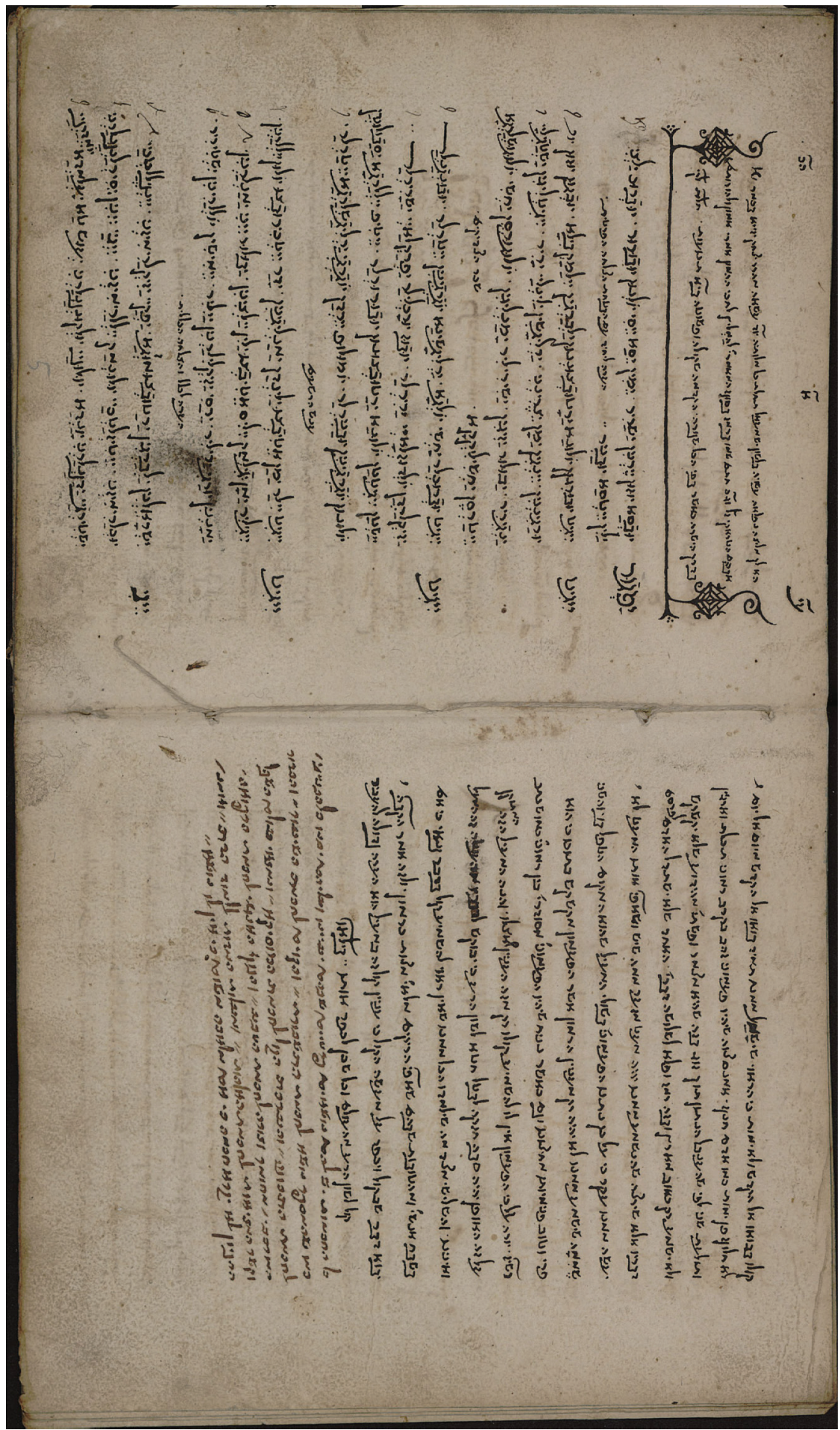

Fig. 2 Manuscript B-1 (Evr IIa 1619 4b-5a, National Library of Russia, St Petersburg). 


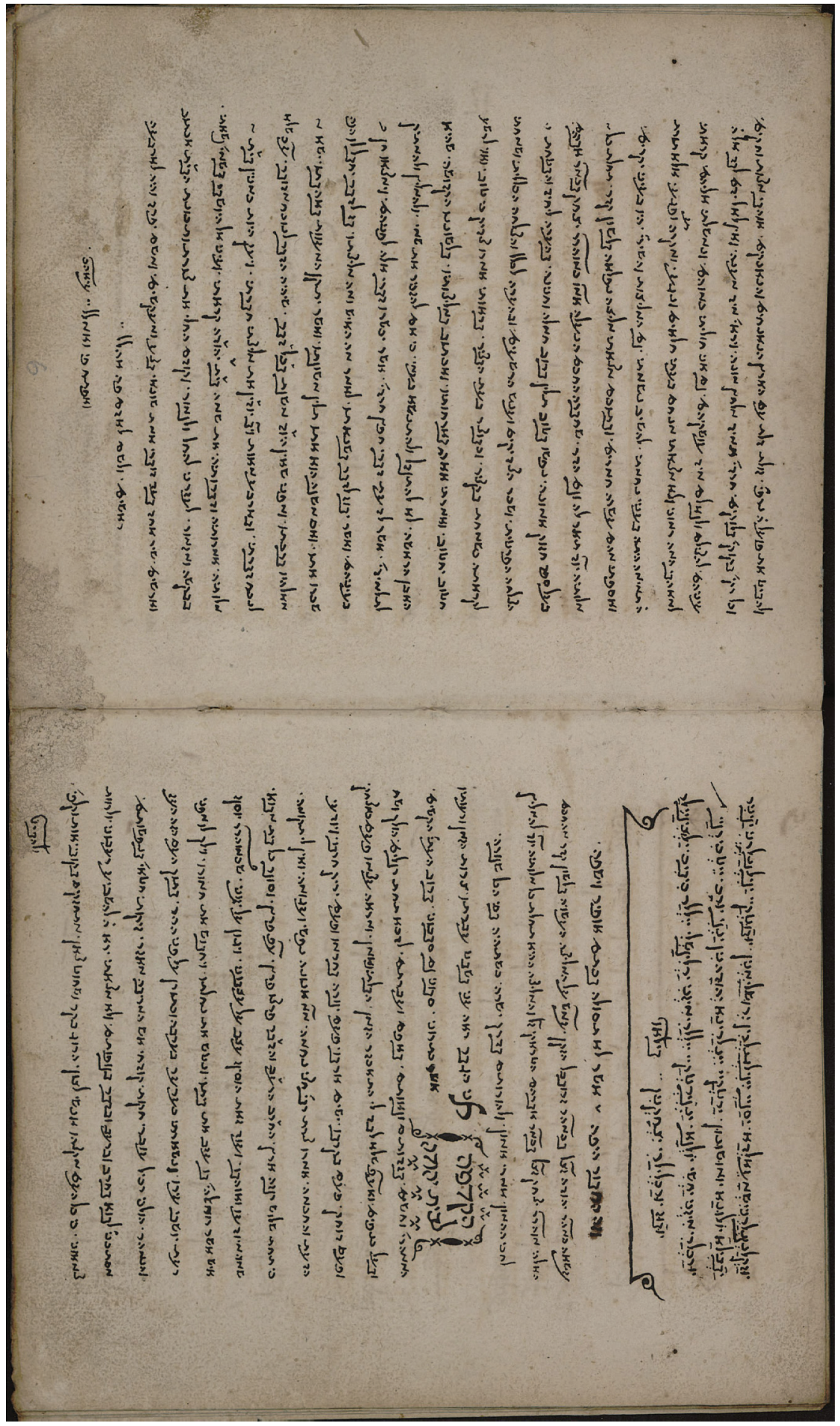

Fig. 3 Manuscript B-2 (Evr IIa 1619 5b-6a, National Library of Russia, St Petersburg). 